\title{
J-shaped Association Between Serum Potassium and 30-day Mortality in Heart Failure: a Secondary Analysis of Cohort Study
}

\author{
Huan Ying Xu \\ Foshan Fosun Chancheng Hospital \\ Zi Qing Jiang \\ Guangzhou University of Chinese Medicine \\ Ying Chen \\ Foshan Clinical Medical School of Guangzhou University of Chinese Medicine \\ Jun Ling Zuo \\ The First Affiliated Hospital of Guangzhou University of Chinese Medicine \\ Su Zhen Wu \\ Foshan Fosun Chancheng Hospital \\ Xiao Liang Zhou ( $\square$ anterliong8871@163.com) \\ Foshan Fosun Chancheng Hospital
}

\section{Research Article}

Keywords: Serum potassium, Heart failure, 30-day mortality, J-shaped relationship

Posted Date: February 7th, 2022

DOI: https://doi.org/10.21203/rs.3.rs-1261193/v1

License: () (1) This work is licensed under a Creative Commons Attribution 4.0 International License. Read Full License 


\section{Abstract}

Background: Multiple observational studies suggest that the association between serum potassium and mortality is U-shaped in heart failure patients, but mostly failed to control for potential confounders of other electrolytes. We explored serum potassium in relation to 30-day mortality in heart failure patients by controlling serum sodium and calcium.

Methods: Data were drawn from Electrolyte imbalances in an unselected population in an emergency department: a retrospective cohort study, Dryad, Dataset, https://doi.org/10.5061/dryad.f3h26j3. This study involved 31,966 patients aged 18 years or older at the emergency department in Diakonhjemmet Hospital in Oslo, Norway, between January 1, 2010 and December 31, 2015. 30-day mortality was examined according to seven predefined potassium levels: 2.60-3.40(hypokalaemia), 3.5-3.8, 3.9-4.1, 4.2-4.4, 4.54.7, 4.80-5.00, and 5.1-7.4(hyperkalemia) $\mathrm{mmol} / \mathrm{L}$. We estimated the risk of 30-day mortality using multivariable logistic regression, with serum potassium at $4.2-4.4 \mathrm{mmol} / \mathrm{L}$ as reference.

Results: A total of 1810 patients were included, and 258 (14.25\%) patients died within 30-day. After multivariable adjustment, the 30-day mortality significantly increased for patients with hyperkalemia $(\mathrm{OR}=2.18,95 \% \mathrm{Cl}: 1.32,3.59)$, but not with normal serum potassium levels: $4.8-5.0 \mathrm{mmol} / \mathrm{L}(\mathrm{OR}=1.08,95 \% \mathrm{Cl}: 0.62,1.87)$, 4.5-4.7mmol/L (OR=1.06, 95\% Cl: 0.67,1.68), 3.9-4.1 mmol/L (OR=1.01, 95\% Cl: $0.65,1.58), 3.5-3.8 \mathrm{mmol} / \mathrm{L}(\mathrm{OR}=0.71,95 \% \mathrm{Cl}: 0.42,1.20)$, nor with hypokalaemia $(\mathrm{OR}=0.89,95 \% \mathrm{Cl}: 0.44,1.80)$. A $\mathrm{J}$-shaped relationship between serum potassium and 30-day mortality was found, with a cut-off point at $4.8 \mathrm{mmol} / \mathrm{L}$. When serum potassium exceeded $4.8 \mathrm{mmol} / \mathrm{L}$, the risk of 30-day mortality increased $192 \%$ for each $1 \mathrm{mmol} / \mathrm{L}$ increase in serum potassium $(\mathrm{OR}=2.92,95 \mathrm{Cl}: 1.74,4.89)$.

Conclusions: J-shaped association between serum potassium and 30-day mortality in heart failure was found, with increased mortality when serum potassium exceeded $4.8 \mathrm{mmol} / \mathrm{L}$.

\section{Introduction}

Heart failure (HF) is a clinical syndrome associated with poor quality of life, substantial healthcare expenditure, and considerable mortality[1-3]. Despite improved treatment regimens, mortality and morbidity remain high[3-5]. Due to underlying pathophysiological processes, concomitant comorbidities, and pharmacological treatments, patients with HF have a vulnerable myocardial function and are susceptible to electrolyte disturbances, common in potassium imbalance[6]. The majority of studies report an association between serum potassium and mortality in patients suffering from acute HF and chronic HF that is U-shaped, with an optimal potassium range that is narrower than the normal reference range[7-11].

Few current studies control for potential confounders of other electrolytes, for instance, serum calcium and sodium, on the relationship between serum potassium and mortality in HF. Serum calcium and sodium are strongly correlated with mortality in HF patients[12-15]. By not controlling for serum calcium and sodium, the available studies may underestimate or overestimate the true effect of serum potassium on mortality in HF patients. Therefore, we performed a secondary data analysis based on previously published data[16], to examine the association between serum potassium and 30-day mortality among patients with HF in a cohort of Norway adults.

\section{Methods}

\subsection{Data Source}

All these dates were obtained from the Dryad Digital Repository (https://datadryad.org/). This website permitted users to download the raw data freely.

According to Dryad Terms of Service, we cited the Dryad data package. Data from: Electrolyte imbalances in an unselected population in an emergency department(ED): a retrospective cohort study, Dryad, Dataset, https://doi.org/10.5061/dryad.f3h26j3[16].

\subsection{Study Design and Participants}

Page 2/16 
This study is a retrospective cohort study at the ED in Diakonhjemmet Hospital, which is a local urban hospital in Oslo, Norway, serves approximately 135000 inhabitants. Briefly, 62991 patient contacts aged 18 years or older were referred for any reason to the ED at Diakonhjemmet Hospital between January 1, 2010, and December 31, 2015, involving 31966 unique patients with laboratory blood analyses.

We included patients diagnosed with HF at the time of discharge( $\mathrm{N}=3829)$. The ICD-10 diagnosis code was I50.0-I50.9 for the main condition or other conditions at the time of discharge. We only included the data from patients' first visit to the ED in this study.2019 patients were excluded for the following reasons: data on second or repeated ED visits for the same patient $(n=1885)$, death days unavailable $(n=15)$, serum potassium missing $(n=5)$, albumin corrected calcium missing $(n=111)$, serum glucose missing $(n=3) .1810$ participants were included in the final analysis(Figure 1).

\subsection{Data Collection and Measurements}

For every visit to the ED, age, sex, serum electrolyte values, and serum albumin, and glucose levels were registered. At Diakonhjemmet Hospital, measurement of serum levels of sodium, potassium, calcium, albumin, and glucose is performed routinely in all medical patients in the ED. Serum sodium levels were corrected for serum glucose by lowering the sodium concentration by $2.4 \mathrm{mmol} / \mathrm{L}$ for every $5.5 \mathrm{mmol} / \mathrm{L}$ increase in glucose, to account for the diluting effect of hyperglycemia[17]. A correction formula was also used to calculate albumin corrected calcium levels[18]. In our study, the main outcome was 30-day mortality.

\subsection{Statistical Analysis}

Frequency and percentage were used in categorical variables, such as gender, comorbidities,30-day mortality. Nonnormally distributed variables are presented as median with interquartile range (IQR), such as age, glucose corrected sodium, serum glucose, albumin corrected calcium, serum albumin. We compared categorical variables and nonnormally distributed variables in different participants, using Pearson's chi-square test and Kruskal-Wallis Rank sum test. Scatter plots with bars were used to display the median (IQR) and the range of serum potassium levels in different participants.

Multivariable logistic regression analyses were performed to study associations between serum potassium levels and 30-day mortality. In our study, we employed multivariate binary logistic regression by constructing three models to explore associations between serum potassium levels and 30-day mortality: model 1 was no covariates adjusted; model 2 was adjusted for age, gender and comorbidities(Diabetes, Hypertension, Kidney failure, Chronic Obstructive Pulmonary Disease, Atrial fibrillation or flutter, Ischemic Heart Disease); model 3 was adjusted age; gender, comorbidities, serum glucose, glucose corrected sodium, serum albumin, and albumin corrected calcium. To explore whether serum potassium levels had a dose-effect and non-linear relationship with 30-day mortality, our statistical analysis consisted of three main steps. Firstly, smooth curve fitting (penalty curve method) was used to address the dose-effect and non-linear relationship of serum potassium levels with 30-day mortality. As the non-linear relationship was found, we further used a two-piece-wise binary logistic regression model to explain the dose-effect relationship of serum potassium levels with 30-day mortality according to the smoothing plot. Log-likelihood ratio test was used to comparing the one-line linear regression model with a two-piece-wise linear model. Secondly, to ensure the robustness of the dose-effect and nonlinear relationship result, we converted serum potassium levels into a categorical variable according to seven intervals. Thirdly, to ensure the robustness of the result, a series of sensitivity analyses were used: (1) The subgroup analyses were performed using stratified binary logistic regression models. Interaction among subgroups was inspected by the likelihood ratio test. (2) We looked at 90-day and 1-year mortality as the secondary outcome. (3) We excluded patients who died on the day of admission for our analysis, considering the impact of critically ill patients on the results of this study.

Data management and analyses were performed with the statistical software package R 3.3.2 (http://www.R-project.org, The R Foundation). A two-tailed test was performed and $p<0.05$ was considered statistically significant.

\section{Results}

\subsection{Baseline characteristics according to serum potassium levels}


Among the 1810 patients from the study, 258 (14.25\%) patients were dead within 30-day. Baseline characteristics of all patients are shown in Table 1. The median age of all patients was 84 years (IQR 76-89 years). 963 (53.20\%) patients were female. The gender, with kidney failure, glucose corrected sodium, serum glucose, serum albumin, and 30-day mortality were showed a significant difference between different serum potassium groups $(\mathrm{p}<0.05)$. The median (IQR) serum potassium levels in patients dead within 30-day were significantly higher than in patients alive beyond 30-days, shown in Figure 2. 
Table 1

Baseline characteristics according to serum potassium levels

\begin{tabular}{|c|c|c|c|c|c|c|c|c|c|}
\hline \multirow[t]{2}{*}{ Characteristics } & \multirow{2}{*}{$\begin{array}{l}\text { All } \\
\text { participants }\end{array}$} & \multicolumn{7}{|c|}{ Serum potassium levels } & \multirow{2}{*}{$\begin{array}{l}\mathrm{P}- \\
\text { value }\end{array}$} \\
\hline & & $\begin{array}{l}2.60- \\
3.40 \\
\mathrm{mmol} / \mathrm{L}\end{array}$ & $\begin{array}{l}3.50- \\
3.80 \\
\mathrm{mmol} / \mathrm{L}\end{array}$ & $\begin{array}{l}3.90- \\
4.10 \\
\mathrm{mmol} / \mathrm{L}\end{array}$ & $\begin{array}{l}4.20- \\
4.40 \\
\mathrm{mmol} / \mathrm{L}\end{array}$ & $\begin{array}{l}4.50- \\
4.70 \\
\mathrm{mmol} / \mathrm{L}\end{array}$ & $\begin{array}{l}4.80- \\
5.00 \\
\mathrm{mmol} / \mathrm{L}\end{array}$ & $\begin{array}{l}5.10- \\
7.40 \\
\mathrm{mmol} / \mathrm{L}\end{array}$ & \\
\hline $\begin{array}{l}\text { Participants } \\
\text { (N) }\end{array}$ & 1810 & 96 & 254 & 396 & 398 & 331 & 177 & 158 & \\
\hline \multicolumn{9}{|l|}{ Gender } & \multirow[t]{3}{*}{$<0.001$} \\
\hline Male & $\begin{array}{l}847 \\
(46.80 \%)\end{array}$ & $\begin{array}{l}32 \\
(33.33 \%)\end{array}$ & $\begin{array}{l}95 \\
(37.40 \%)\end{array}$ & $\begin{array}{l}182 \\
(45.96 \%)\end{array}$ & $\begin{array}{l}183 \\
(45.98 \%)\end{array}$ & $\begin{array}{l}165 \\
(49.85 \%)\end{array}$ & $\begin{array}{l}94 \\
(53.11 \%)\end{array}$ & $\begin{array}{l}96 \\
(60.76 \%)\end{array}$ & \\
\hline Female & $\begin{array}{l}963 \\
(53.20 \%)\end{array}$ & $\begin{array}{l}64 \\
(66.67 \%)\end{array}$ & $\begin{array}{l}159 \\
(62.60 \%)\end{array}$ & $\begin{array}{l}214 \\
(54.04 \%)\end{array}$ & $\begin{array}{l}215 \\
(54.02 \%)\end{array}$ & $\begin{array}{l}166 \\
(50.15 \%)\end{array}$ & $\begin{array}{l}83 \\
(46.89 \%)\end{array}$ & $\begin{array}{l}62 \\
(39.24 \%)\end{array}$ & \\
\hline \multirow{2}{*}{$\begin{array}{l}\text { Age, years, } \\
\text { median (IQR) }\end{array}$} & 84.00 & 85.00 & 85.00 & 84.00 & 84.00 & 84.00 & 84.00 & 84.00 & \multirow[t]{2}{*}{0.134} \\
\hline & $\begin{array}{l}(76.00- \\
89.00)\end{array}$ & $\begin{array}{l}(78.75- \\
91.25)\end{array}$ & $\begin{array}{l}(78.00- \\
90.00)\end{array}$ & $\begin{array}{l}(77.00- \\
89.00)\end{array}$ & $\begin{array}{l}(76.00- \\
89.00)\end{array}$ & $\begin{array}{l}(74.00- \\
89.00)\end{array}$ & $\begin{array}{l}(75.00- \\
89.00)\end{array}$ & $\begin{array}{l}(77.00- \\
89.00)\end{array}$ & \\
\hline \multicolumn{10}{|l|}{ Comorbidities } \\
\hline Diabetes & $\begin{array}{l}185 \\
(10.22 \%)\end{array}$ & $\begin{array}{l}8 \\
(8.33 \%)\end{array}$ & $\begin{array}{l}18 \\
(7.09 \%)\end{array}$ & $\begin{array}{l}34 \\
(8.59 \%)\end{array}$ & $\begin{array}{l}43 \\
(10.80 \%)\end{array}$ & $\begin{array}{l}36 \\
(10.88 \%)\end{array}$ & $\begin{array}{l}25 \\
(14.12 \%)\end{array}$ & $\begin{array}{l}21 \\
(13.29 \%)\end{array}$ & 0.167 \\
\hline Hypertension & $\begin{array}{l}270 \\
(14.92 \%)\end{array}$ & $\begin{array}{l}17 \\
(17.71 \%)\end{array}$ & $\begin{array}{l}39 \\
(15.35 \%)\end{array}$ & $\begin{array}{l}65 \\
(16.41 \%)\end{array}$ & $\begin{array}{l}61 \\
(15.33 \%)\end{array}$ & $\begin{array}{l}42 \\
(12.69 \%)\end{array}$ & $\begin{array}{l}28 \\
(15.82 \%)\end{array}$ & $\begin{array}{l}18 \\
(11.39 \%)\end{array}$ & 0.632 \\
\hline Kidney failure & $\begin{array}{l}312 \\
(17.24 \%)\end{array}$ & $\begin{array}{l}11 \\
(11.46 \%)\end{array}$ & $\begin{array}{l}29 \\
(11.42 \%)\end{array}$ & $\begin{array}{l}63 \\
(15.91 \%)\end{array}$ & $\begin{array}{l}55 \\
(13.82 \%)\end{array}$ & $\begin{array}{l}50 \\
(15.11 \%)\end{array}$ & $\begin{array}{l}47 \\
(26.55 \%)\end{array}$ & $\begin{array}{l}57 \\
(36.08 \%)\end{array}$ & $<0.001$ \\
\hline COPD & $\begin{array}{l}200 \\
(11.05 \%)\end{array}$ & $\begin{array}{l}7 \\
(7.29 \%)\end{array}$ & $\begin{array}{l}20 \\
(7.87 \%)\end{array}$ & $\begin{array}{l}41 \\
(10.35 \%)\end{array}$ & $\begin{array}{l}49 \\
(12.31 \%)\end{array}$ & $\begin{array}{l}38 \\
(11.48 \%)\end{array}$ & $\begin{array}{l}23 \\
(12.99 \%)\end{array}$ & $\begin{array}{l}22 \\
(13.92 \%)\end{array}$ & 0.330 \\
\hline $\begin{array}{l}\text { Atrial } \\
\text { fibrillation } \\
\text { or flutter }\end{array}$ & $\begin{array}{l}732 \\
(40.44 \%)\end{array}$ & $\begin{array}{l}46 \\
(47.92 \%)\end{array}$ & $\begin{array}{l}103 \\
(40.55 \%)\end{array}$ & $\begin{array}{l}166 \\
(41.92 \%)\end{array}$ & $\begin{array}{l}157 \\
(39.45 \%)\end{array}$ & $\begin{array}{l}131 \\
(39.58 \%)\end{array}$ & $\begin{array}{l}80 \\
(45.20 \%)\end{array}$ & $\begin{array}{l}49 \\
(31.01 \%)\end{array}$ & 0.111 \\
\hline IHD & $\begin{array}{l}467 \\
(25.80 \%)\end{array}$ & $\begin{array}{l}15 \\
(15.62 \%)\end{array}$ & $\begin{array}{l}61 \\
(24.02 \%)\end{array}$ & $\begin{array}{l}108 \\
(27.27 \%)\end{array}$ & $\begin{array}{l}111 \\
(27.89 \%)\end{array}$ & $\begin{array}{l}77 \\
(23.26 \%)\end{array}$ & $\begin{array}{l}48 \\
(27.12 \%)\end{array}$ & $\begin{array}{l}47 \\
(29.75 \%)\end{array}$ & 0.146 \\
\hline \multirow{2}{*}{$\begin{array}{l}\text { Glucose } \\
\text { corrected } \\
\text { sodium, } \\
\text { mmol/L, } \\
\text { median (IQR) }\end{array}$} & 140.00 & 140.48 & 140.34 & 140.25 & 139.68 & 139.91 & 139.70 & 139.24 & \multirow[t]{2}{*}{0.031} \\
\hline & $\begin{array}{l}(137.26- \\
142.31)\end{array}$ & $\begin{array}{l}(137.62- \\
142.59)\end{array}$ & $\begin{array}{l}(138.30- \\
142.59)\end{array}$ & $\begin{array}{l}(137.98- \\
142.36)\end{array}$ & $\begin{array}{l}(137.43- \\
142.00)\end{array}$ & $\begin{array}{l}(136.56- \\
142.14)\end{array}$ & $\begin{array}{l}(136.04- \\
142.03)\end{array}$ & $\begin{array}{l}(136.05- \\
142.03)\end{array}$ & \\
\hline \multirow{3}{*}{$\begin{array}{l}\text { Serum } \\
\text { glucose, } \\
\text { mmol/L, } \\
\text { median } \\
\text { (IQR) }\end{array}$} & 6.70 & 6.90 & 6.90 & 6.40 & 6.80 & 6.70 & 6.70 & 6.75 & \multirow[t]{3}{*}{0.040} \\
\hline & $(5.80-8.20)$ & $\begin{array}{l}(6.07- \\
7.93)\end{array}$ & $\begin{array}{l}(5.90- \\
8.47)\end{array}$ & $\begin{array}{l}(5.70- \\
7.70)\end{array}$ & $\begin{array}{l}(5.90- \\
8.00)\end{array}$ & $\begin{array}{l}(5.80- \\
8.40)\end{array}$ & $\begin{array}{l}(5.90- \\
8.90)\end{array}$ & $\begin{array}{l}(5.80- \\
8.60)\end{array}$ & \\
\hline & & & & & & & & & \\
\hline \multirow{2}{*}{$\begin{array}{l}\text { Albumin } \\
\text { corrected } \\
\text { calcium, } \\
\text { mmol/L, } \\
\text { median (IQR) }\end{array}$} & 2.39 & 2.41 & 2.38 & 2.38 & 2.39 & 2.39 & 2.39 & 2.40 & \multirow[t]{2}{*}{0.696} \\
\hline & $(2.32-2.46)$ & $\begin{array}{l}(2.32- \\
2.49)\end{array}$ & $\begin{array}{l}(2.31- \\
2.45)\end{array}$ & $\begin{array}{l}(2.32- \\
2.46)\end{array}$ & $\begin{array}{l}(2.32- \\
2.46)\end{array}$ & $\begin{array}{l}(2.32- \\
2.46)\end{array}$ & $\begin{array}{l}(2.32- \\
2.46)\end{array}$ & $\begin{array}{l}(2.33- \\
2.45)\end{array}$ & \\
\hline
\end{tabular}

Abbreviation: IQR, interquartile range;COPD, chronic obstructive pulmonary disease; IHD, Ischemic Heart Disease. 


\begin{tabular}{|c|c|c|c|c|c|c|c|c|c|}
\hline \multirow[t]{2}{*}{ Characteristics } & \multirow{2}{*}{$\begin{array}{l}\text { All } \\
\text { participants }\end{array}$} & \multicolumn{7}{|c|}{ Serum potassium levels } & \multirow{2}{*}{$\begin{array}{l}\mathrm{P}- \\
\text { value }\end{array}$} \\
\hline & & $\begin{array}{l}2.60- \\
3.40 \\
\mathrm{mmol} / \mathrm{L}\end{array}$ & $\begin{array}{l}3.50- \\
3.80 \\
\mathrm{mmol} / \mathrm{L}\end{array}$ & $\begin{array}{l}3.90- \\
4.10 \\
\mathrm{mmol} / \mathrm{L}\end{array}$ & $\begin{array}{l}4.20- \\
4.40 \\
\mathrm{mmol} / \mathrm{L}\end{array}$ & $\begin{array}{l}4.50- \\
4.70 \\
\mathrm{mmol} / \mathrm{L}\end{array}$ & $\begin{array}{l}4.80- \\
5.00 \\
\mathrm{mmol} / \mathrm{L}\end{array}$ & $\begin{array}{l}5.10- \\
7.40 \\
\mathrm{mmol} / \mathrm{L}\end{array}$ & \\
\hline \multirow{2}{*}{$\begin{array}{l}\text { Serum } \\
\text { albumin, } \\
\text { g/L, median } \\
\text { (IQR) }\end{array}$} & 37.00 & 36.00 & 37.00 & 38.00 & 38.00 & 38.00 & 37.00 & 36.00 & \multirow[t]{2}{*}{$<0.001$} \\
\hline & $\begin{array}{l}(34.00- \\
40.00)\end{array}$ & $\begin{array}{l}(33.00- \\
38.25)\end{array}$ & $\begin{array}{l}(34.00- \\
39.00)\end{array}$ & $\begin{array}{l}(34.00- \\
40.00)\end{array}$ & $\begin{array}{l}(35.00- \\
40.00)\end{array}$ & $\begin{array}{l}(35.00- \\
40.00)\end{array}$ & $\begin{array}{l}(34.00- \\
40.00)\end{array}$ & $\begin{array}{l}(33.00- \\
39.00)\end{array}$ & \\
\hline
\end{tabular}

\subsection{Association between serum potassium levels and 30-day mortality}

The odds ratio of 30-day mortality was $1.72(95 \% \mathrm{Cl}: 1.38,2.13)$ for per $1 \mathrm{mmol} / \mathrm{L}$ increment in serum potassium levels in unadjusted (Table 2). The result was sustained after adjusted for age, gender, and comorbidities ( $\mathrm{OR}=1.53,95 \% \mathrm{Cl}$ : 1.22,1.92).In model 3, we adjusted for age, gender, comorbidities, serum glucose, glucose corrected sodium, serum albumin, and albumin corrected calcium, the odds ratio of 30-day mortality was 1.58 (95\% Cl: 1.25,1.99). 
Table 2

The odds ratios and $95 \% \mathrm{Cl}$ for 30 -day mortality association with serum potassium levels.

\begin{tabular}{|c|c|c|c|c|c|c|c|c|}
\hline \multirow[t]{2}{*}{ Exposure } & \multirow{2}{*}{$\begin{array}{l}\text { Alive } \\
(\mathrm{n}, \%)\end{array}$} & \multirow{2}{*}{$\begin{array}{l}\text { 30-day } \\
\text { mortality (n, \%) }\end{array}$} & \multicolumn{2}{|l|}{ Model 1} & \multicolumn{2}{|l|}{ Model 2} & \multicolumn{2}{|l|}{ Model 3} \\
\hline & & & $\begin{array}{l}\mathrm{OR}(95 \% \\
\mathrm{Cl})\end{array}$ & $\begin{array}{l}\mathrm{P} \\
\text { Value }\end{array}$ & $\begin{array}{l}\mathrm{OR}(95 \% \\
\mathrm{Cl})\end{array}$ & $\begin{array}{l}\mathrm{P} \\
\text { Value }\end{array}$ & $\begin{array}{l}\text { OR }(95 \% \\
\mathrm{Cl})\end{array}$ & $\begin{array}{l}\mathrm{P} \\
\text { Value }\end{array}$ \\
\hline $\begin{array}{l}\text { Serum } \\
\text { potassium, } \\
\mathrm{mmol} / \mathrm{L}\end{array}$ & $1552(85.75 \%)$ & $258(14.25 \%)$ & $\begin{array}{l}1.72 \\
(1.38 \\
2.13)\end{array}$ & $<0.001$ & $\begin{array}{l}1.53(1.22 \\
1.92)\end{array}$ & $<0.001$ & $\begin{array}{l}1.58 \\
(1.25,1.99)\end{array}$ & $<0.001$ \\
\hline \multicolumn{9}{|c|}{ Seven serum potassium intervals } \\
\hline $5.10-7.40 \mathrm{mmol} / \mathrm{L}$ & $111(70.25 \%)$ & $47(29.75 \%)$ & $\begin{array}{l}2.95 \\
(1.88 \\
4.63)\end{array}$ & $<0.001$ & $\begin{array}{l}2.39 \\
(1.48,3.85)\end{array}$ & $<0.001$ & $\begin{array}{l}2.18 \\
(1.32,3.59)\end{array}$ & 0.002 \\
\hline $4.80-5.00 \mathrm{mmol} / \mathrm{L}$ & $150(84.75 \%)$ & $27(15.25 \%)$ & $\begin{array}{l}1.25 \\
(0.76 \\
2.08)\end{array}$ & 0.382 & $\begin{array}{l}1.13 \\
(0.67,1.90)\end{array}$ & 0.656 & $\begin{array}{l}1.08 \\
(0.62,1.87)\end{array}$ & 0.788 \\
\hline $4.50-4.70 \mathrm{mmol} / \mathrm{L}$ & $288(87.01 \%)$ & $43(12.99 \%)$ & $\begin{array}{l}1.04 \\
(0.67 \\
1.61)^{\prime}\end{array}$ & 0.863 & $\begin{array}{l}1.03 \\
(0.66,1.61)\end{array}$ & 0.896 & $\begin{array}{l}1.06 \\
(0.67,1.68)\end{array}$ & 0.805 \\
\hline $4.20-4.40 \mathrm{mmol} / \mathrm{L}$ & $348(87.44 \%)$ & $50(12.56 \%)$ & Ref & & Ref & & Ref & \\
\hline $3.90-4.10 \mathrm{mmol} / \mathrm{L}$ & $347(87.63 \%)$ & $49(12.37 \%)$ & $\begin{array}{l}0.98 \\
(0.65 \\
1.50)\end{array}$ & 0.936 & $\begin{array}{l}0.96 \\
(0.62,1.48)\end{array}$ & 0.847 & $\begin{array}{l}1.01 \\
(0.65,1.58)\end{array}$ & 0.969 \\
\hline $3.50-3.80 \mathrm{mmol} / \mathrm{L}$ & $225(88.58 \%)$ & $29(11.42 \%)$ & $\begin{array}{l}0.90 \\
(0.55 \\
1.46)\end{array}$ & 0.662 & $\begin{array}{l}0.87 \\
(0.53,1.43)\end{array}$ & 0.580 & $\begin{array}{l}0.71 \\
(0.42,1.20)\end{array}$ & 0.203 \\
\hline $2.60-3.40 \mathrm{mmol} / \mathrm{L}$ & $83(86.46 \%)$ & $13(13.54 \%)$ & $\begin{array}{l}1.09 \\
(0.57 \\
2.10)^{\prime}\end{array}$ & 0.796 & $\begin{array}{l}1.14 \\
(0.58,2.24)\end{array}$ & 0.697 & $\begin{array}{l}0.89 \\
(0.44,1.80)\end{array}$ & 0.746 \\
\hline \multicolumn{9}{|c|}{ Abbreviation: OR, odds ratios; $\mathrm{Cl}$, confidence interval. Ref, reference group; } \\
\hline \multicolumn{9}{|c|}{ Model 1 was unadjusted. } \\
\hline \multicolumn{9}{|c|}{ Model 2 was adjusted for: Age; Gender; Diabetes; Hypertension; Kidney failure; COPD; Atrial fibrillation or flutter; IHD. } \\
\hline
\end{tabular}

We converted serum potassium levels into a categorical variable according to seven intervals. with serum potassium 4.2$4.4 \mathrm{mmol} / \mathrm{L}$ as reference,the 30-day mortality significantly increased in hyperkalemia patients $(5.1-7.4 \mathrm{mmol} / \mathrm{L}, \mathrm{OR}=2.18,95 \%$ $\mathrm{Cl}: 1.32,3.59)$. While, risk of 30-day mortality was not increased significantly in normal potassium :4.80-5.00 mmol/L (OR=1.08, $95 \% \mathrm{Cl}: 0.62,1.87), 4.50-4.70 \mathrm{mmol} / \mathrm{L}(\mathrm{OR}=1.06,95 \% \mathrm{Cl}: 0.67,1.68), 3.90-4.10 \mathrm{mmol} / \mathrm{L}(\mathrm{OR}=1.01,95 \% \mathrm{Cl}: 0.65,1.58), 3.50-3.80$ $\mathrm{mmol} / \mathrm{L}(\mathrm{OR}=0.71,95 \% \mathrm{Cl}: 0.42,1.20)$, nor in hypokalaemia: $2.60-3.40 \mathrm{mmol} / \mathrm{L}(\mathrm{OR}=0.89,95 \% \mathrm{Cl}: 0.44,1.80)$.

\subsection{Dose-effect analysis of the relationship between serum potassium levels and 30-day mortality}

By smoothing curve fitting (penalty curve method) analysis, we found a J-shaped association between serum potassium levels and the risk of 30-day mortality, with a cut-off point at $4.8 \mathrm{mmol} / \mathrm{L}$ (Figure 3, Table 3).In figure 3, the full line represents the estimated risk of 30-day mortality, and the dotted lines represent point-wise $95 \%$ confidence intervals adjusted for age, gender, comorbidities, serum glucose, glucose corrected sodium, serum albumin, albumin corrected calcium. When serum potassium levels were lower than $4.8 \mathrm{mmol} / \mathrm{L}$, the OR for 30-day mortality was $1.10(95 \% \mathrm{Cl}: 0.78,1.57)$. However, the risk of 30-day mortality was increased with the serum potassium levels higher than $4.8 \mathrm{mmol} / \mathrm{L}(\mathrm{OR}=2.92,95 \mathrm{Cl}: 1.74,4.89)$, indicating a $192 \%$ increased risk of 
30-day mortality with $1 \mathrm{mmol} / \mathrm{L}$ increased serum potassium levels. The log-likelihood ratio test was significant with a two-piecewise linear model $(P=0.009)$.

Table 3

Threshold effect analysis of the relationship between serum potassium levels and the risk of 30-day mortality

\begin{tabular}{|c|c|c|}
\hline Outcome: & OR $(95 \% \mathrm{Cl})$ & $P$ value \\
\hline One-line linear regression model & $1.58(1.25,1.99)$ & $<0.001$ \\
\hline \multicolumn{3}{|c|}{ Two-piecewise linear regression model } \\
\hline Serum-potassium $\leq 4.8 \mathrm{mmol} / \mathrm{L}$ & $1.10(0.78,1.57)$ & 0.581 \\
\hline Serum-potassium $₫ 4.8 \mathrm{mmol} / \mathrm{L}$ & $2.92(1.74,4.89)$ & $<0.001$ \\
\hline Log-likelihood ratio test & & 0.009 \\
\hline Abbreviation: OR, odds ratios; $\mathrm{Cl}, \mathrm{co}$ & & \\
\hline
\end{tabular}

\subsection{Sensitivity analyses of the relationship between serum potassium levels and 30-day mortality}

We performed three sensitivity analyses to test the robustness of our results. First, subgroup and interactive analysis showed that the association between serum potassium levels and 30-day mortality was stable in different subgroups (Figure 4).

The result showed that the association between serum potassium levels and 30-day mortality was stable in different subgroups. Second, we used serum potassium levels as a categorical variable to investigate the relationship between different serum potassium levels and 30-day mortality in each subgroup. The results were robust, in which hyperkalemia (5.1-7.4 mmol/L) increased significantly the risk of 30-day mortality in different subgroups, while hypokalaemia (2.60-3.40 mmol/L) had no significant association with 30-day mortality, with serum potassium $4.2-4.4 \mathrm{mmol} / \mathrm{L}$ as reference (Table $1 \mathrm{~S}$ ). Third, we looked at 90-day and 1-year mortality as the outcome and the results were similar to the main analysis (Table 2S). Finally, we excluded patients who died on the day of admission for our analysis, considering the impact of critically ill patients on the results of this study. This analysis did not change our conclusions (Table 3S).

\section{Discussion}

In our study, we found that a J-shaped association between serum potassium levels and the risk of 30-day mortality, with a cut-off point at $4.8 \mathrm{mmol} / \mathrm{L}$. Serum potassium above $4.8 \mathrm{mmol} / \mathrm{L}$ was also associated with increased 30-day mortality, after controlling for potential confounders of age, gender, comorbidities, serum glucose, glucose corrected sodium, serum albumin, and albumin corrected calcium.

Multiple studies implicated that hyperkalemia and hypokalaemia are both associated with an increased risk of mortality in HF patients. Kroger et al.[7] reported that the relationship between serum potassium and short-term mortality in patients with acute HF after myocardial infarction is U-shaped, with an optimal potassium range of 3.9-4.5 mmol/L. Subsequently, research[8] in patients with chronic HF showed a similar U-shaped relationship, with an optimal potassium range between 4.2-4.7 $\mathrm{mmol} / \mathrm{L}$. In the same line, research[10] in patients with new-onset HF also demonstrated a U-shaped relationship between serum potassium and mortality, with the risk of death being lowest in the range of $4.5-4.9 \mathrm{mmol} / \mathrm{L}$.

Most studies failed to control for potential confounders of other electrolytes, for instance, serum calcium and sodium. Previous studies showed that electrolyte abnormalities were often correlated with poor outcomes in HF[13,14, 19-22]. Therefore, we considered the effect of serum sodium and calcium to investigate the association between serum potassium and 30-day mortality 
in HF patients. Moreover, to control more potential confounding factors, glucose corrected sodium and albumin corrected calcium was used in our study.

In our threshold effect analysis, the risk of 30-day mortality increased in the serum potassium levels above $4.8 \mathrm{mmol} / \mathrm{L}$ (OR=2.92, $95 \mathrm{Cl}: 1.74,4.89)$, suggesting even high potassium levels within the accepted normal range of potassium were associated with increased mortality. We also found hyperkalemia was associated with an increased risk of 90 -day mortality $(\mathrm{OR}=2.18,95 \% \mathrm{Cl}$ : 1.32,3.59). Sehoon Park et al.[23] suggested that increased serum potassium levels, including mild elevations, may be related to worse prognosis in hospitalized patients. Thomsen et al.[24] indicated that hyperkalemia was associated with acute-care hospitalization and death in patients with HF. Younis et al.[25] found that admission $\mathrm{K}>5.5 \mathrm{mEq} / \mathrm{L}$ was independently associated with increased short- and long-term mortality among hospitalized patients with HF. While another study[11] showed hyperkalemia was associated only with increased short-term mortality but not long-term mortality in patients with HF. Similarly, in our sensitivity analyses, hyperkalemia had no significant independent association with 1-year mortality after adjustment (OR=1.30,95\%:

$0.85,1.98)$. Therefore, hyperkalemia had been largely recognized as a risk factor for short-term mortality. Nevertheless, it is not clear whether hyperkalemia is a risk factor for long-term mortality.

We discover that low serum potassium levels $(2.6-3.4 \mathrm{mmol} / \mathrm{L})$ had no significant association with 30-day mortality and long-term mortality. Similarly, previous research in hospitalized older patients with HF and acute HF patients reported that hypokalaemia(K+ $<3.5 \mathrm{mmol} / \mathrm{L}$ )had no association with mortality or other outcomes[26, 27]. This lack of an association between hypokalaemia and 30-day mortality and long-term mortality in HF is in contrast with studies mentioned above[7, 8, 10] and may be due to varying according to patient characteristics.

Firstly, the median age of these studies $[7,8,10]$ was 74 years, while patients with hypokalaemia were older (median age 84 years compared) in our study and usually with a higher comorbidity burden, indicating a higher proportion of noncardiovascular death, which would be less likely to be affected by a low serum potassium level[28]. Secondly, these patients who visit the ED would be expected to have more advanced HF, with poor heart function and higher mortality, suggesting that the cause of death is more likely to die from pump failure than from sudden cardiac death. In previous studies[29, 30] showed that pump failure death is the predominant mode of death in patients with advanced HF and acute HF patients, secondly to sudden cardiac death. If a higher proportion of patients visiting the ED in our study had more advanced HF and died because of pump failure, which makes it difficult to find the association between low potassium and 30-day mortality. Thirdly, 963/1810(53.2\%) were female in our studies, and $66.67 \%$ of women had hypokalemia. Hypokalemia can lead to arrhythmias and sudden cardiac death in patients. Pooja Dewan indicated that the lower risk of cardiovascular death in women, compared with men, was in part explained by a substantially lower risk of sudden death. [31]Robert W. Rho discovered that throughout a range of total mortality risk, women had a $20 \%$ lower all-cause mortality and $30 \%$ fewer deaths that were sudden compared with men[32]. The population attributable risk of sudden cardiac death is higher in men than women. Pump failure is a more common mode of death in women[32]. The leading cause of death in heart failure patients remains cardiovascular death, and then that would in part explain the higher number of women in our study but the lack of association of hypokalaemia with 30-day mortality.

Our study has several limitations. Our study was a secondary data analysis based on previously published data. Since the electronic patient journal systems in Norway are not searchable, some potentially confounding variables were not available, including past medical history, the reason for visiting and vital status in the ED, and known history of chronic electrolyte imbalances. The published data only offered the administrative data (age, sex, electrolyte levels, diagnoses, readmission, and mortality). Information on medications such as potassium-sparing diuretics, ACE inhibitors/ARBs, or loop diuretics was not available. Although impaired potassium homeostasis, as a consequence of the above medication treatment, is frequently observed in clinical, the use of these drugs significantly reduces outcomes in heart failure patients. Therefore, despite the lack of medication use in this study, it is noteworthy that the potential resulting from treatment would bias toward to the null and thus result in an underestimation of the association between serum potassium and 30-day mortality. The published data did not provide the rate of primary prevention ICD implants as ICDs would be expected to reduce the rate of 30-day mortality due to arrhythmias or sudden cardiac death, which are certainly possible in patients with electrolyte abnormalities. Information on ejection fraction or physical activity was not available, so we were unable to subdivide our heart failure patients according e.g. reduced or preserved ejection fraction or the stages of HF. We will consider the effect of type of HF and stage of HF on the association between serum potassium and mortality in our future study. The mechanism of death was also not evaluated. This could lead to an 
overestimation of the risk when looking at cardiovascular death. Since we are examining mortality over a short period after a diagnosis of heart failure, we did not find it beneficial to distinguish between cardiovascular and non-cardiovascular death. We only identified heart failure patients if they had an ED visit, and this limits the generalizability of these findings as their 30-day mortality may be related to underlying decompensation or other medical conditions that prompted an ED visit. Finally, due to the observational design, we cannot exclude the possibility of residual confounding of the reported associations. It is necessary to include a larger cohort with standardized data collections in future studies to further validate these results.

\section{Conclusion}

J-shaped association between serum potassium and 30-day mortality in heart failure was found, with increased mortality when serum potassium exceeded $4.8 \mathrm{mmol} / \mathrm{L}$.

\section{Abbreviations}

$H F$, heart failure;

OR, odds ratios;

$\mathrm{Cl}$, confidence interval;

ED,emergency department;

$\mathrm{IQR}$, interquartile range;

\section{Declarations}

\section{Ethics approval and consent to participate}

Our study was carried out in accordance with relevant guidelines and regulations of the Strengthening the Reporting of Observational Studies in Epidemiology (STROBE). Our study was exempt from institutional review board oversight, because the Dryad database is accessible to the public and the patients in the database are de-identified. The research committee of Diakonhjemmet Hospital approved this study and waived informed consent because the data were unidentified. The author removed the following variables to protect participant identity: the time of blood tests, the date of patients visited the ED, the date of discharge out of the hospital, the date of death.

\section{Consent for publication}

The manuscript is approved by all authors for publication.

\section{Availability of Data and Materials}

All Data from "Electrolyte imbalances in an unselected population in an emergency department: a retrospective cohort study", Dryad, Dataset, https://doi.org/10.5061/dryad.f3h26j3.

\section{Conflict of Interest}

None.

\section{Funding}

This research did not receive any specific grant from funding agencies in the public, commercial, or not-for-profit sectors.

\section{Author's contribution}


Huan Ying Xu: Conceptualization, Methodology, Formal analysis, Data Curation, Writing - Original Draft. Zi Qing Jiang: Conceptualization, Methodology, Writing - Original Draft. Ying Chen: Formal analysis, Writing - Original Draft. Jun Ling Zuo: Conceptualization, Writing - Review \& Editing. Su Zhen Wu, Xiao Liang Zhou: Conceptualization, Methodology, Writing - Review \& Editing.

\section{Acknowledgements}

The authors express their sincere appreciation to all participants in this cohort study. We sincerely thank the medical staff in the emergency department of Diakonhjemmet Hospital, Oslo, Norway. We gratefully thank Kiarash Tazmini's professor for his contribution to this research area and the data support.

\section{References}

1. Heidenreich PA, Albert NM, Allen LA, Bluemke DA, Butler J, Fonarow GC, Ikonomidis JS, Khavjou O, Konstam MA, Maddox $\mathrm{TM}$ et al: Forecasting the impact of heart failure in the United States: a policy statement from the American Heart Association. Circ Heart Fail 2013, 6(3):606-619.

2. Writing Committee M, Yancy CW, Jessup M, Bozkurt B, Butler J, Casey DE, Jr., Drazner MH, Fonarow GC, Geraci SA, Horwich T et al: 2013 ACCF/AHA guideline for the management of heart failure: a report of the American College of Cardiology Foundation/American Heart Association Task Force on practice guidelines. Circulation 2013, 128(16):e240-327.

3. Ponikowski P, Voors AA, Anker SD, Bueno H, Cleland JG, Coats AJ, Falk V, Gonzalez-Juanatey JR, Harjola VP, Jankowska EA et al: 2016 ESC Guidelines for the diagnosis and treatment of acute and chronic heart failure: The Task Force for the diagnosis and treatment of acute and chronic heart failure of the European Society of Cardiology (ESC). Developed with the special contribution of the Heart Failure Association (HFA) of the ESC. Eur J Heart Fail 2016, 18(8):891-975.

4. Mosterd A, Hoes AW: Clinical epidemiology of heart failure. Heart 2007, 93(9):1137-1146.

5. Roger VL: Epidemiology of heart failure. Circ Res 2013, 113(6):646-659.

6. Savarese G, Xu H, Trevisan M, Dahlstrom U, Rossignol P, Pitt B, Lund LH, Carrero JJ: Incidence, Predictors, and Outcome Associations of Dyskalemia in Heart Failure With Preserved, Mid-Range, and Reduced Ejection Fraction. JACC Heart Fail 2019, 7(1):65-76.

7. Krogager ML, Eggers-Kaas L, Aasbjerg K, Mortensen RN, Kober L, Gislason G, Torp-Pedersen C, Sogaard P: Short-term mortality risk of serum potassium levels in acute heart failure following myocardial infarction. Eur Heart $J$ Cardiovasc Pharmacother 2015, 1(4):245-251.

8. Aldahl M, Jensen AC, Davidsen L, Eriksen MA, Moller Hansen S, Nielsen BJ, Krogager ML, Kober L, Torp-Pedersen C, Sogaard P: Associations of serum potassium levels with mortality in chronic heart failure patients. Eur Heart J 2017, 38(38):2890-2896.

9. Krogager ML, Torp-Pedersen C, Mortensen RN, Kober L, Gislason G, Sogaard P, Aasbjerg K: Short-term mortality risk of serum potassium levels in hypertension: a retrospective analysis of nationwide registry data. Eur Heart J 2017, 38(2):104-112.

10. Linde C, Qin L, Bakhai A, Furuland H, Evans M, Ayoubkhani D, Palaka E, Bennett H, McEwan P: Serum potassium and clinical outcomes in heart failure patients: results of risk calculations in 21334 patients in the UK. ESC Heart Fail 2019, 6(2):280-290.

11. Cooper LB, Benson L, Mentz RJ, Savarese G, DeVore AD, Carrero JJ, Dahlstrom U, Anker SD, Lainscak M, Hernandez AF et al: Association between potassium level and outcomes in heart failure with reduced ejection fraction: a cohort study from the Swedish Heart Failure Registry. Eur J Heart Fail 2020, 22(8):1390-1398.

12. Breen T, Brueske B, Sidhu MS, Murphree DH, Kashani KB, Barsness GW, Jentzer JC: Abnormal Serum Sodium is Associated With Increased Mortality Among Unselected Cardiac Intensive Care Unit Patients. J Am Heart Assoc 2020, 9(2):e014140.

13. Shirakabe A, Kiuchi K, Kobayashi N, Okazaki H, Matsushita M, Shibata Y, Shigihara S, Sawatani T, Tani K, Otsuka Y et al: Importance of the Corrected Calcium Level in Patients With Acute Heart Failure Requiring Intensive Care. Circulation reports 2020, 3(1):44-54.

14. Jensen AC, Polcwiartek C, Sogaard P, Mortensen RN, Davidsen L, Aldahl M, Eriksen MA, Kragholm K, Torp-Pedersen C, Hansen SM: The Association Between Serum Calcium Levels and Short-Term Mortality in Patients with Chronic Heart Failure. Am J Med 2019, 132(2):200-208 e201. 
15. Lutsey PL, Alonso A, Michos ED, Loehr LR, Astor BC, Coresh J, Folsom AR: Serum magnesium, phosphorus, and calcium are associated with risk of incident heart failure: the Atherosclerosis Risk in Communities (ARIC) Study. Am J Clin Nutr 2014, 100(3):756-764.

16. Tazmini K, Nymo SH, Louch WE, Ranhoff AH, Oie E: Electrolyte imbalances in an unselected population in an emergency department: A retrospective cohort study. PloS one 2019, 14(4):e0215673.

17. Hillier TA, Abbott RD, Barrett EJ: Hyponatremia: evaluating the correction factor for hyperglycemia. Am J Med 1999, 106(4):399-403.

18. Rustad P, Felding P, Franzson L, Kairisto V, Lahti A, Martensson A, Hyltoft Petersen P, Simonsson P, Steensland H, Uldall A: The Nordic Reference Interval Project 2000: recommended reference intervals for $\mathbf{2 5}$ common biochemical properties. Scand J Clin Lab Invest 2004, 64(4):271-284.

19. Urso C, Brucculeri S, Caimi G: Acid-base and electrolyte abnormalities in heart failure: pathophysiology and implications. Heart failure reviews 2015, 20(4):493-503.

20. Yoo BS, Park JJ, Choi DJ, Kang SM, Hwang JJ, Lin SJ, Wen MS, Zhang J, Ge J, investigators C: Prognostic value of hyponatremia in heart failure patients: an analysis of the Clinical Characteristics and Outcomes in the Relation with Serum Sodium Level in Asian Patients Hospitalized for Heart Failure (COAST) study. Korean J Intern Med 2015, 30(4):460-470.

21. Polcwiartek C, Hansen SM, Kragholm K, Krogager ML, Aldahl M, Kober L, Torp-Pedersen C, Jensen SE, Sogaard P: Prognostic role of serum sodium levels across different serum potassium levels in heart failure patients: A Danish register-based cohort study. Int J Cardiol 2018, 272:244-249.

22. Nishihara T, Tokitsu T, Sueta D, Takae M, Oike F, Fujisue K, Usuku H, Takashio S, Hanatani S, Kanazawa H et al: Serum Potassium and Cardiovascular Events in Heart Failure With Preserved Left Ventricular Ejection Fraction Patients. Am J Hypertens 2018, 31(10):1098-1105.

23. Park S, Baek SH, Lee SW, Lee A, Chin HJ, Na KY, Kim YS, Chae DW, Han JS, Kim S: Elevated baseline potassium level within reference range is associated with worse clinical outcomes in hospitalised patients. Scientific reports 2017, 7(1):2402.

24. Thomsen RW, Nicolaisen SK, Hasvold P, Garcia-Sanchez R, Pedersen L, Adelborg K, Egfjord M, Egstrup K, Sorensen HT: Elevated Potassium Levels in Patients With Congestive Heart Failure: Occurrence, Risk Factors, and Clinical Outcomes: A Danish Population-Based Cohort Study. J Am Heart Assoc 2018, 7(11).

25. Younis A, Goldenberg I, Goldkorn R, Younis A, Peled Y, Tzur B, Klempfner R: Elevated Admission Potassium Levels and 1-Year and 10-Year Mortality Among Patients With Heart Failure. Am J Med Sci 2017, 354(3):268-277.

26. Valentova M, Patel S, Lam PH, Faselis C, Arundel C, Fonarow GC, Cheng Y, Allman RM, von Haehling S, Anker SD et al: Hypokalaemia and outcomes in older patients hospitalized for heart failure. ESC heart failure 2020, 7(3):794-803.

27. Legrand M, Ludes PO, Massy Z, Rossignol P, Parenica J, Park JJ, Ishihara S, AlHabib KF, Maggioni A, Miro 0 et al: Association between hypo- and hyperkalemia and outcome in acute heart failure patients: the role of medications. Clin Res Cardio/ 2018, 107(3):214-221.

28. Zile MR, Gaasch WH, Anand IS, Haass M, Little WC, Miller AB, Lopez-Sendon J, Teerlink JR, White M, McMurray JJ et al: Mode of death in patients with heart failure and a preserved ejection fraction: results from the Irbesartan in Heart Failure With Preserved Ejection Fraction Study (I-Preserve) trial. Circulation 2010, 121(12):1393-1405.

29. Carson P, Anand I, O'Connor C, Jaski B, Steinberg J, Lwin A, Lindenfeld J, Ghali J, Barnet JH, Feldman AM et al: Mode of death in advanced heart failure: the Comparison of Medical, Pacing, and Defibrillation Therapies in Heart Failure (COMPANION) trial. J Am Coll Cardiol 2005, 46(12):2329-2334.

30. O'Connor CM, Miller AB, Blair JE, Konstam MA, Wedge P, Bahit MC, Carson P, Haass M, Hauptman PJ, Metra M et al: Causes of death and rehospitalization in patients hospitalized with worsening heart failure and reduced left ventricular ejection fraction: results from Efficacy of Vasopressin Antagonism in Heart Failure Outcome Study with Tolvaptan (EVEREST) program. Am Heart J 2010, 159(5):841-849 e841.

31. Dewan P, Rorth R, Raparelli V, Campbell RT, Shen L, Jhund PS, Petrie MC, Anand IS, Carson PE, Desai AS et al: Sex-Related Differences in Heart Failure With Preserved Ejection Fraction. Circ Heart Fail 2019, 12(12):e006539.

32. Rho RW, Patton KK, Poole JE, Cleland JG, Shadman R, Anand I, Maggioni AP, Carson PE, Swedberg K, Levy WC: Important differences in mode of death between men and women with heart failure who would qualify for a primary prevention 


\section{Figures}

Patient visits in Emergency Department between January 1, 2010, and December 31,2015

$\mathrm{N}=62991$

\begin{tabular}{|c|c|}
\hline \multicolumn{2}{|c|}{$\begin{array}{l}\text { Patients diagnosed with heart failure. The ICD-10 diagnosis code were } \\
\text { I50.0-I50.9 for the main condition or other conditions at the time of discharge. } \\
\mathbf{N}=\mathbf{3 8 2 9}\end{array}$} \\
\hline & $\begin{array}{l}2019 \text { participants were excluded: } \\
\text { Data on second or repeated emergency department visits } \\
\text { for the same patient, } n=1885 \\
\text { Death days unavailable, } n=15 \\
\text { Serum potassium missing, } n=5 \\
\text { Albumin corrected calcium missing, } n=111 \\
\text { Serum glucose missing, } n=3\end{array}$ \\
\hline $\begin{array}{l}\text { Patients it } \\
\mathbf{N}=\mathbf{1 8 1 0}\end{array}$ & final analysis. \\
\hline
\end{tabular}

Figure 1

Flow chart of participants selection. Abbreviation: ICD, International Classification of Diseases. 
$P<0.001$
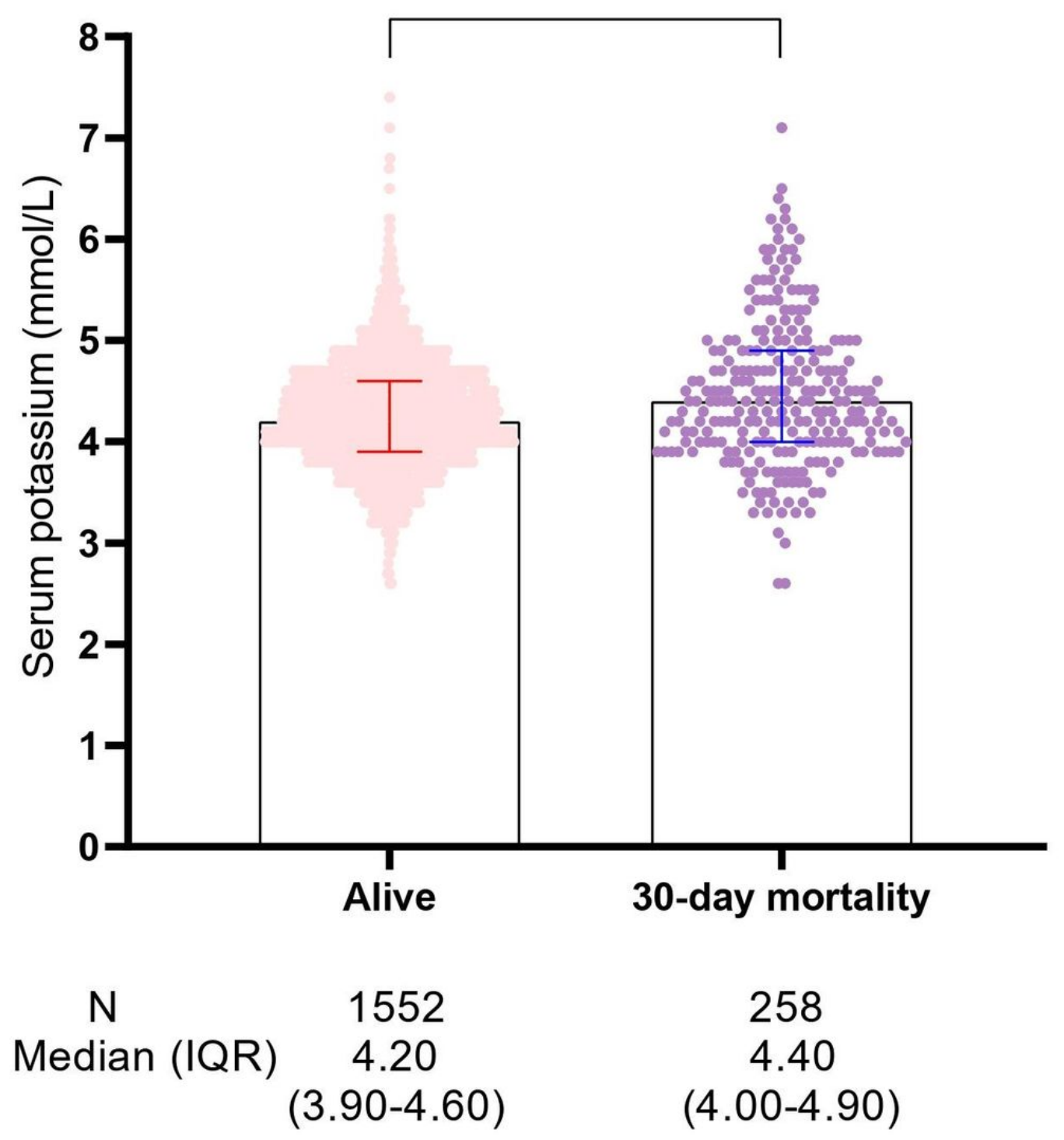

Figure 2

Serum potassium levels in different participants. Abbreviation: IQR, interquartile range. 


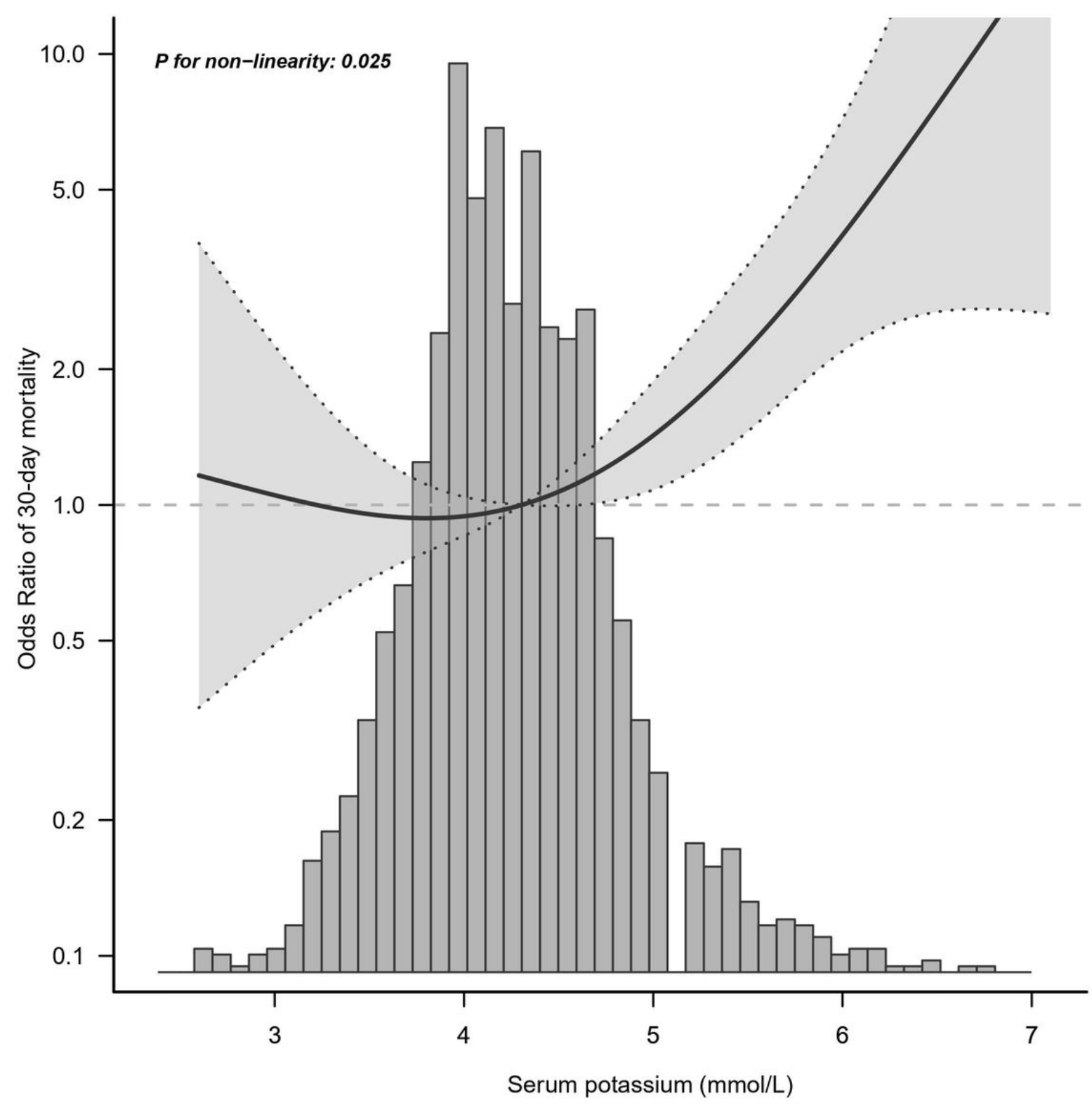

Figure 3

Dose-effect relationship between serum potassium levels and 30-day mortality. Abbreviation: OR, odds ratios. The full line represents the estimated risk of 30-day mortality, and the dotted lines represent point-wise $95 \%$ confidence intervals adjusted for age, gender, comorbidities, serum glucose, glucose corrected sodium, serum albumin, albumin corrected calcium. 


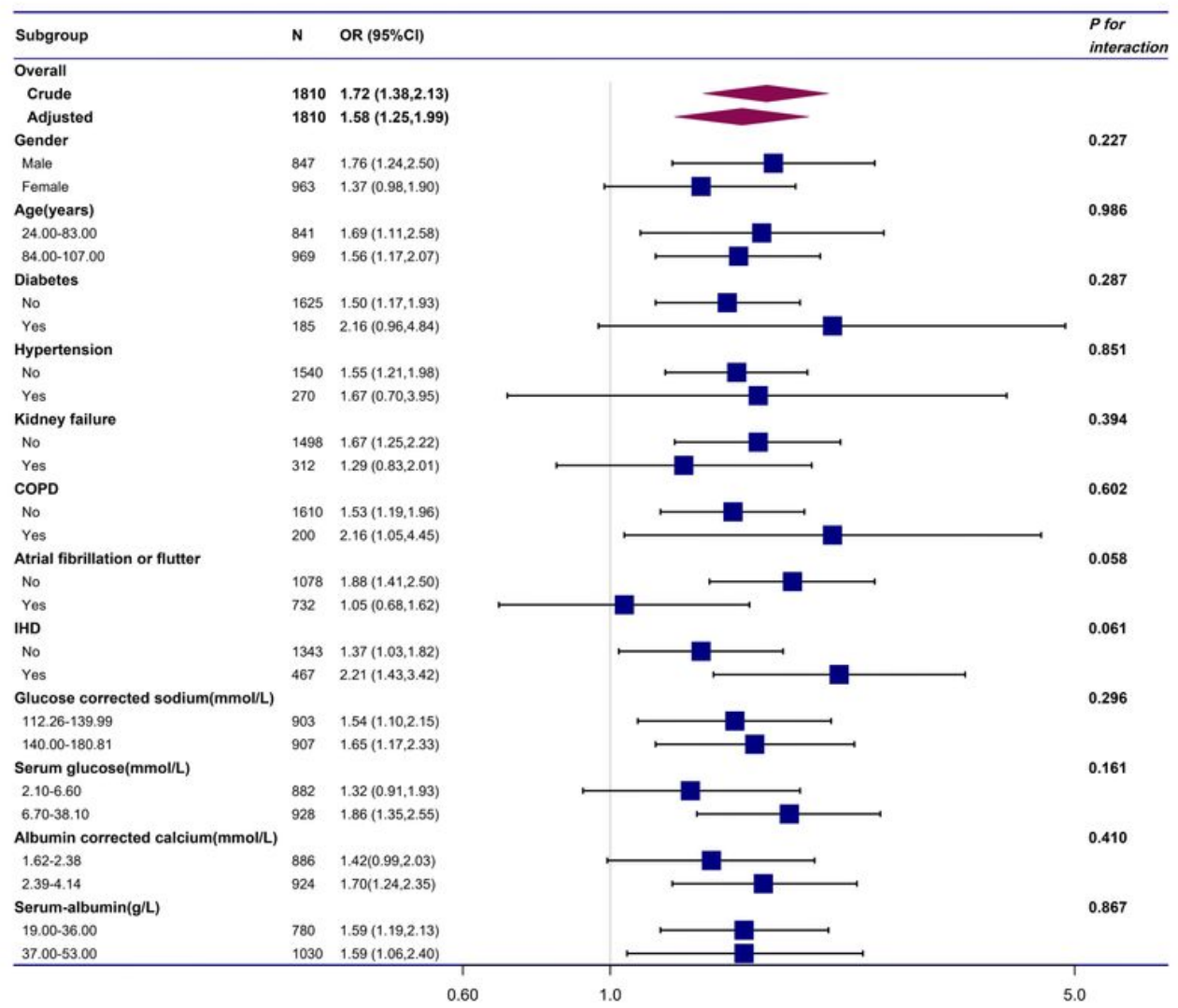

Figure 4

Subgroup analysis of the association of serum potassium levels with 30-day mortality. Abbreviation: OR, odds ratios; $\mathrm{Cl}$, confidence interval. The model was adjusted for age, gender, diabetes; hypertension; kidney failure; COPD; atrial fibrillation or flutter; IHD; serum glucose; glucose corrected serum sodium; serum albumin; albumin corrected calcium.

\section{Supplementary Files}

This is a list of supplementary files associated with this preprint. Click to download.

- TableS1S3.docx 